\title{
Microbial colonization in diverse surface soil types in Surtsey and diversity analysis of its subsurface microbiota
}

\author{
V. Marteinsson ${ }^{1,3}$, A. Klonowski ${ }^{1}$, E. Reynisson ${ }^{1}$, P. Vannier ${ }^{1}$, B. D. Sigurdsson ${ }^{3}$, and M. Ólafsson ${ }^{2}$ \\ ${ }^{1}$ Matís, Food safety, Environment \& Genetics, Vínlandsleið 12, 113 Reykjavík, Iceland \\ 2'́́SOR, Gensásvegi 9, 108 Reykjavík, Iceland \\ ${ }^{3}$ Agricultural University of Iceland, Hvanneyri, 311 Borgarnes, Iceland \\ Correspondence to: V. Marteinsson (viggo@matis.is)
}

Received: 1 April 2014 - Published in Biogeosciences Discuss.: 22 September 2014

Revised: 13 January 2015 - Accepted: 16 January 2015 - Published: 24 February 2015

\begin{abstract}
Colonization of life on Surtsey has been observed systematically since the formation of the island 50 years ago. Although the first colonisers were prokaryotes, such as bacteria and blue-green algae, most studies have been focused on the settlement of plants and animals but less on microbial succession. To explore microbial colonization in diverse soils and the influence of associated vegetation and birds on numbers of environmental bacteria, we collected 45 samples from different soil types on the surface of the island. Total viable bacterial counts were performed with the plate count method at 22,30 and $37^{\circ} \mathrm{C}$ for all soil samples, and the amount of organic matter and nitrogen (N) was measured. Selected samples were also tested for coliforms, faecal coliforms and aerobic and anaerobic bacteria. The subsurface biosphere was investigated by collecting liquid subsurface samples from a $181 \mathrm{~m}$ borehole with a special sampler. Diversity analysis of uncultivated biota in samples was performed by $16 \mathrm{~S}$ rRNA gene sequences analysis and cultivation. Correlation was observed between nutrient deficits and the number of microorganisms in surface soil samples. The lowest number of bacteria $\left(1 \times 10^{4}-1 \times 10^{5}\right.$ cells $\left.\mathrm{g}^{-1}\right)$ was detected in almost pure pumice but the count was significantly higher $\left(1 \times 10^{6}-1 \times 10^{9}\right.$ cells $\left.\mathrm{g}^{-1}\right)$ in vegetated soil or pumice with bird droppings. The number of faecal bacteria correlated also to the total number of bacteria and type of soil. Bacteria belonging to Enterobacteriaceae were only detected in vegetated samples and samples containing bird droppings. The human pathogens Salmonella, Campylobacter and Listeria were not in any sample. Both thermophilic bacteria and archaea $16 \mathrm{~S}$ rDNA sequences were found in the subsurface samples collected at 145 and $172 \mathrm{~m}$ depth at 80
\end{abstract}

and $54^{\circ} \mathrm{C}$, respectively, but no growth was observed in enrichments. The microbiota sequences generally showed low affiliation to any known 16S rRNA gene sequences.

\section{Introduction}

Microorganisms are typically in great abundance and high diversity in common soil and their integrated activity drives nutrient cycling on the ecosystem scale. Organic matter (OM) inputs from plant production support microbial heterotrophic soil communities that also drive processes that make nutrients available in the system. This, in turn, supports plant primary productivity and basic food webs on the ground and in the subsurface (Fenchel et al., 2012; Roesch et al., 2007; Schlesinger, 1997; Whitman et al., 1998). Moreover, as soil develops, soil geochemistry and OM availability changes (Vitousek and Farrington, 1997) due to mineral-OM interactions and geochemical constraints on biological activity (Kleber et al., 2007; Sinsabaugh et al., 2008). Nutrient limitations can constrain plant and food web development, thus shaping the rate of succession of plant and animal life within the ecosystem (Odum, 1969; Walker and del Moral, 2003).

Subsequent to volcanic eruption, lava flow and ash deposition, new surfaces are created where both organismal growth and weathering processes are effectively reset. Microbial cells colonizing new volcanic deposits must be successful in either growing autotrophically, by fixing carbon (C) and $\mathrm{N}$ using light or inorganic energy sources for growth, e.g. Cyanobacteria and sulfate-reducing bacteria (Edwards et al., 2003; Ernst, 1908; Konhauser et al., 2002), using carbon 
monoxide as a $\mathrm{C}$ and energy source (Dunfield and King, 2004; King and Weber, 2008) or by growing heterotrophically using trace amounts of organic carbon (Cockell et al., 2009; Wu et al., 2007). Studies on the microbiota of volcanic terrains have only emerged within the past few years, revealing that such habitats are capable of harbouring significant microbial diversity, despite their extreme nature (GomezAlvarez et al., 2007; Kelly et al., 2010). However, completely isolated volcanic terrains, such as islands, are extremely rare. One of few such places is Surtsey, a neo-volcanic island, created by a series of volcanic eruption that started in 1963 and ended in 1967 (Pórarinsson, 1965, 1967, 1968). The eruption was thoroughly documented from the first plume of ash until the end of the lava flow in June 1967. In 1979 a $181 \mathrm{~m}$ deep hole was drilled to investigate the substructure of the volcano as well as the nature of the hydrothermal system (Jakobsson and Moore, 1979). Consequently, with its drill hole the island of Surtsey provides a unique laboratory for the investigation of biological establishment and succession on relatively newly deposited volcanic substrata, on the surface and in the subsurface. The first reports of life forms in Surtsey were from 1964 to 1966 (Brock, 1966; Friðriksson, 1965), when the first cyanobacteria were observed, even before the end of the eruption. Phototrophs were further investigated in 1968 (Schwabe, 1970) and in subsequent investigations in following years (Brock, 1973; Schwabe and Behre, 1972). However, despite such a remarkable habitat, very little research on microbiology has been performed since the first years of the island formation despite frequent research expeditions; the most recent report on microbes in Surtsey is only from the end of last century (Frederiksen et al., 2000). Additionally, no reports or data exist on heterotrophic growth or distribution of such bacteria in the surface soils of the island, and nothing is known about distribution of faecal bacteria or pathogens possibly brought by bird inputs of organic matter, such as faeces. Additionally, even less is known about the island's subsurface life although such life is well known in subseafloor sediments and within the deep biosphere where high number of microbes are present and active (Kallmeyer et al., 2012).

The overall aim of this study was to explore microbial colonization in different surface soil types and in the subsurface below $160 \mathrm{~m}$ depth in a drill hole in Surtsey. That was done by obtaining viable count and distribution of heterotrophic microbes on the island surface and by obtaining the correlation of nutrients and other environmental measurements to different soil types, and determining how that affects microbial communities in Surtsey. We also accomplished this by investigating the presence, survival and possible dissemination routes of pathogenic bacteria into such pristine environments. Finally, the existence and diversity of subsurface microbial biosphere and their possible dissemination routes was investigated.

\section{Material and methods}

\subsection{Surface sampling and study sites}

Samples were collected during a sample expedition at Surtsey in July 2009. An about $1.0 \mathrm{~cm}$ thick layer was retrieved inside a frame of $20 \times 20 \mathrm{~cm}\left(0.04 \mathrm{~m}^{2}\right)$ with a spoon that was washed with $70 \%$ ethanol between samples. Samples were collected in a sterile plastic box and stored outside in the shade and then at $4{ }^{\circ} \mathrm{C}$ upon arrival to the laboratory in Reykjavík, until they were processed. Samples were retrieved all around the island and the GPS location of each sample taken (Fig. 1). The samples can be divided into three types (Fig. 2), SS samples (sand or pumice with bird droppings), SJ samples (pure sand or pumice) and SR samples (vegetated, partly vegetated and non-vegetated area), taken at permanent study plots in Surtsey (Magnússon et al., 2014).

\subsubsection{Media and cultural conditions}

The basic methodology used at the laboratory for media and culturing were NMKL methods (Nordisk Metodikkomité for Næringsmidler) and methods from the Compendium of Methods for the Microbiological Examination of Foods published by the American Public Health Association (APHA2001). About $25 \mathrm{~g}$ of each surface sample was weighed and $225 \mathrm{~mL}$ Peptone water was mixed in before using a stomacher for blending the soil for $1 \mathrm{~min}$. The supernatant of each sample was used and analysed with different methods.

\subsubsection{Total viable count of environmental bacteria}

The conventional "pour-plate" method was used on plate count agar. Briefly, $1 \mathrm{~mL}$ of homogenate sample was used with $20 \mathrm{~mL}$ melted and cooled culture medium. Incubation temperatures were at 22 and $30^{\circ} \mathrm{C}$ for $72 \mathrm{~h}$ in aerobic and anaerobic conditions. The total viable count was also estimated by filtering $0.1,1,10$ and $100 \mathrm{~mL}$ samples through a sterile $0.22 \mu \mathrm{m}$ cellulose membrane filter (Millipore Corporation, MA, USA) to capture microbial cells and placed onto Reasoner's 2A (R2A) agar (Difco, Kansas, USA) and incubated at $22^{\circ} \mathrm{C}$ for $4-5$ days for evaluation of total viable count. For better results, $20 \mathrm{~mL}$ of sterile phosphate buffer (FB) was used with the 0.1 and $1 \mathrm{~mL}$ samples to increase the volume filtered, allowing better dispersion of cells to be grown on the filter paper. All 44 surface samples were tested with these methods and the results expressed as $\mathrm{cfu}^{-1}$.

\subsubsection{Total coliforms, faecal coliforms and Escherichia coli}

A reference method based on most probable number (MPN) from NMKL (NMKL 96, 4th ed., 2009, Compendium 4th ed., 2001 , chapter $8(8.71,8.72,8.81))$ was used to estimate total coliforms, faecal coliforms and Escherichia coli. Pre- 


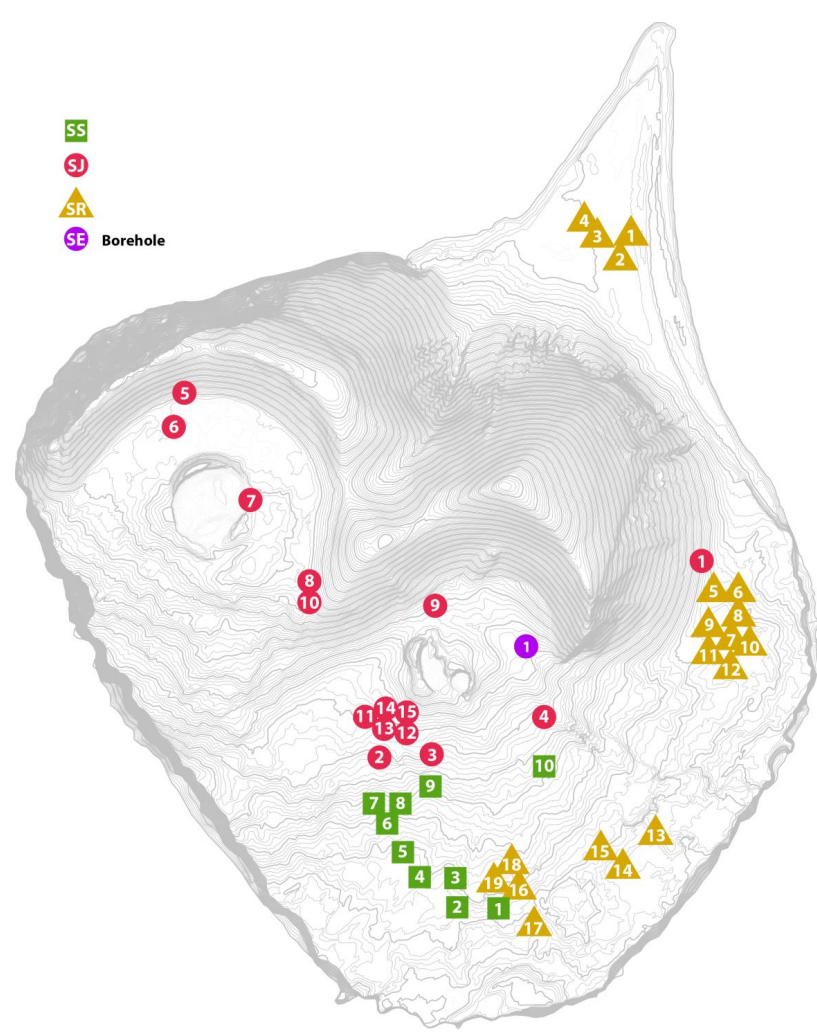

Figure 1. An overview of the sampling site. The sites are marked with green squares for sand or pumice with bird droppings samples (SS), pink circles for pure sand or pumice and vegetated samples (SJ), yellow triangles for partly vegetated and non-vegetated area samples (SR) collected inside squares for activity measurements and purple circle for the drill hole site (SE). The sampling sites are distributed according to GPS points.

enrichment was done in LST broth $\left(37^{\circ} \mathrm{C}\right.$ for $\left.48 \mathrm{~h}\right)$ and confirmation tests were done in BGLB broth for total coliforms $\left(37^{\circ} \mathrm{C}\right.$ for $\left.48 \mathrm{~h}\right)$ and in EC broth for faecal coliforms $\left(44^{\circ} \mathrm{C}\right.$ for $24 \mathrm{~h})$. Escherichia coli was confirmed by the testing of indole production. The expression of results are in $\mathrm{cfu}^{-1}$.

\subsubsection{Total viable count of Enterobacteriaceae}

A reference method from NMKL (reference: NMKL 144, 3rd ed., 2005) was used to estimate total Enterobacteriaceae in all 44 surface samples. The medium violet red bile glucose agar (VRBGA) was used (pour-plate method with overlay). Plates were incubated for $24 \mathrm{~h}$ at $37^{\circ} \mathrm{C}$ and typical colonies counted. Oxidase test was used for confirmation. The expression of results is $\mathrm{cfu}^{-1}$.

\subsubsection{Detection of pathogens}

Reference methods from NMKL was used to estimate total number of pathogens or for Salmonella, Campylobacter and Listeria. The following NMKL method (reference: NMKL
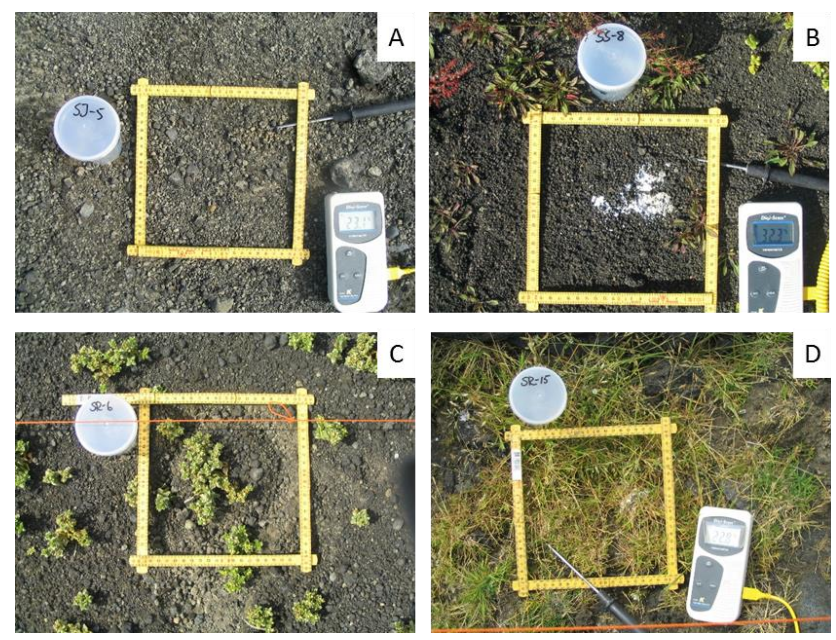

Figure 2. Pictures of the sample types. Samples were divided into three types: SJ samples ((a) barren sand or pumice without bird droppings, see SJ-5), SS samples ((b) barren sand or pumice with bird droppings, see SS-8) and SR samples ((c) partly vegetated surfaces, see SR-6; and (d) totally vegetated surfaces, see SR-15).

71, 5th ed., 1999, ISO 6579:2002, Wellcolex-serogroup identification) was used for Salmonella detection. Briefly, preenrichment was done in BPW broth $\left(37^{\circ} \mathrm{C}\right.$ for $\left.24 \mathrm{~h}\right), 25 \mathrm{~g}$ into $225 \mathrm{~mL}$ of enrichment broth. Second enrichment was done in $\mathrm{RV}$ broth $\left(41.5^{\circ} \mathrm{C}\right.$ for $\left.24 \mathrm{~h}\right)$ and tetrathionate broth $\left(41.5^{\circ} \mathrm{C}\right.$ for $24 \mathrm{~h}$ ). Broths from these enrichments were streaked onto two solid media: XLD and $\mathrm{BG}\left(37^{\circ} \mathrm{C}\right.$ for $\left.24 \mathrm{~h}\right)$. Typical colonies (2-4 or as needed) were inoculated into TSI- and LI-agar slants $\left(37^{\circ} \mathrm{C}\right.$ for $\left.24 \mathrm{~h}\right)$. Confirmation was done by testing for flagellar $(H)$ and somatic $(O)$ antigens. The expression of results was pos/neg in $25 \mathrm{~g}$ and 17 selected surface samples were tested.

The following NMKL method (NMKL 119, 3rd ed., 2007) was used for Campylobacter jejuni/coli detection. Briefly, enrichment was done in Bolton broth, $11 \mathrm{~g}$ of sample into $100 \mathrm{~mL}$ of enrichment broth. $\left(41.5^{\circ} \mathrm{C}\right.$ for $\left.48 \mathrm{~h}\right)$. Broths from these enrichments were streaked onto mCCDA agar and incubated at $41.5^{\circ} \mathrm{C}$ for $48 \mathrm{~h}$ in an anaerobic jar with microaerobic atmosphere. The expression of results is pos/neg in $11 \mathrm{~g}$, and 17 selected surface samples were tested (NMKL 119, 3rd ed., 2007).

The following NMKL method (reference: NMKL 136, 5th ed., 2010) was used for Listeria monocytogenes detection. Briefly, pre-enrichment in Listeria broth, $25 \mathrm{~g}$ into $225 \mathrm{~mL}$ of enrichment broth $\left(30^{\circ} \mathrm{C}\right.$ for $\left.24 \mathrm{~h}\right)$. Then, further inoculation was done in Fraser broth $\left(37^{\circ} \mathrm{C}\right.$ for up to $\left.48 \mathrm{~h}\right)$. Both primary and secondary enrichment cultures were streaked onto Oxford and OCLA agar $\left(37^{\circ} \mathrm{C}\right.$ for 24 and $\left.48 \mathrm{~h}\right)$. Confirmation tests were done on five colonies from each plate and include gram-staining, catalase and motility. Species identification includes haemolysis on blood agar and testing on API Listeria (System for the identification of Listeria, bioMérieux 
SA, France). The expression of results was pos/neg in $25 \mathrm{~g}$ and 17 selected surface samples were tested.

\subsubsection{Soil geochemistry, chemical and soil moisture analysis}

The total amount of nitrogen (totN\%) was measured on a nitrogen analyser (Foss Tecator Kjeltec 2400 Analyzer Unit). About $3 \mathrm{~g}$ of soil was analysed at $420^{\circ} \mathrm{C}$ for $2.5 \mathrm{~h}$ according to the ISO method 5983-2:2005. The total amount of carbon (totC\%) was calculated from loss on ignition after heating at $550{ }^{\circ} \mathrm{C}$ for $4 \mathrm{~h}$ assuming the organic matter contained $50 \%$ carbon according to the ISO method 5984-2002 (E). Soil gravimetric water content (GWC) was measured as the mass lost from soil after drying $5 \mathrm{~g}$ of soil for $24 \mathrm{~h}$ at $103^{\circ} \mathrm{C}$.

\subsection{7 $\mathrm{CO}_{2}$ flux measurements}

The measurement of net ecosystem exchange (NEE, $\mu \mathrm{mol} \mathrm{CO}_{2} \mathrm{~m}^{-2} \mathrm{~s}^{-1}$ ) and ecosystem respiration (Re, $\mu \mathrm{mol}$ $\mathrm{CO}_{2} \mathrm{~m}^{-2} \mathrm{~s}^{-1}$ ) were performed as described by Sigurdsson and Magnússon (2010) on top of microbial samples marked as SR samples that were collected from permanent vegetation survey plots, which are $10 \times 10 \mathrm{~m}$ in area (Magnússon et al., 2014; Sigurdsson and Magnússon, 2010). Briefly, an EGM-4 infrared gas analyser and a CPY-2 transparent respiration chamber (PP Systems, UK) were first used to measure NEE in light, which was measured as photosynthetically active radiation (PAR) inside the chamber. Then, Re was subsequently measured in dark by covering the chamber. The total gross ecosystem $\mathrm{CO}_{2}$ uptake rate (GPP), was then calculated by the difference between Re and NEE. Vegetation surface cover (Cov., \%) was also recorded under the flux chamber at each measurement point and soil temperature was recorded at 5 and $10 \mathrm{~cm}$ depth $\left(\mathrm{Ts} 05\right.$ and $\left.\mathrm{Ts} 10,{ }^{\circ} \mathrm{C}\right)$ with a temperature probe placed adjacent to the respiration chamber.

\subsubsection{Multivariate analysis of measured parameters}

Multivariate analysis was performed on the environmental parameters collected in order to visualize environmental similarities between sample sites. The parameters were temperature, total carbon, total nitrogen, water content, total microbial count of PCA and counts of Enterobacteriaceae. Samples containing missing values were excluded in the analysis except in six occasions were total nitrogen values were not available. In these cases, the values were estimated based on other similar samples in the data set. The other option would have been to exclude these samples from the analysis. Data were normalized with $\ln (x \times+0.1)$ or $\ln (x \times+1)$, the latter for bacterial counts and standardized with ( $x$-mean) / SD. Nonmetric multidimensional scaling (NMDS) using Euclidean similarity measures were performed (Ramette, 2007) using the environmental statistical analysis program PAST.

\subsection{Subsurface sampling}

\subsubsection{Sampling and temperature data}

The subsurface was sampled through continuously cored drill hole SE-1 (Moore, 1982; Ólafsson and Jakobsson, 2009). The temperature was measured along the drill hole at $1 \mathrm{~m}$ intervals from the surface down to the bottom at $180 \mathrm{~m}$ with a borehole temperature meter. A temperature logger (DST milli-PU logger from StarOddi, Reykjavík, Iceland) was placed for approximately $21 \mathrm{~h}$ at $168 \mathrm{~m}$ depth in the borehole and the temperature was recorded every $15 \mathrm{~min}$ with SeaStar software. Samples were collected in an in-house created downhole water sampler made of stainless steel. The total capacity of the sampler is about $1.3 \mathrm{~L}$ that was kept open (flow through) to the sampling depth and closed with a messenger. Contamination of samples were avoided by washing the sampler with several equivalent volumes of $70 \%$ ethanol before operation. Samples SB1, 2, 4, 5 and 6 were retrieved from 57, 58, 145, 168 and $170 \mathrm{~m}$, respectively. Samples SB4, 5 and 6 were sampled below the sea level $(58 \mathrm{~m})$. Samples were reduced by $\mathrm{Na}_{2} \mathrm{~S}$ solution $(0.05 \% w / v$ final concentration) and kept under anaerobic conditions at low temperature during the field trip and at $4{ }^{\circ} \mathrm{C}$ in the laboratory.

\subsubsection{Enrichment cultures of subsurface samples}

Media for enrichment of chemolithotrophic and chemoorganotrophic organisms were prepared by using $0.5 \mathrm{~mL}$ sample and $4.5 \mathrm{~mL} 0.2 \mu \mathrm{m}$ filtered water from the subsurface samples. Cultures were incubated under aerobic (ambient headspace) and anaerobic conditions at 40,60 and $80^{\circ} \mathrm{C}$. Each enrichment was prepared in Hungate culture tubes with $0.01 \%$ yeast extract, vitamin solution, Balch element solution (Balch et al., 1979), $\mathrm{S}^{0}$ and resazurin and incubated under pure $\mathrm{N}_{2}$ and $0.025 \%$ final $w / v \mathrm{Na}_{2} \mathrm{~S} \times 9 \mathrm{H}_{2} \mathrm{O}$, same but aerobically with ambient headspace and incubation with $80 / 20 \% \mathrm{H}_{2} / \mathrm{CO}_{2}$ and $0.025 \%$ final $w / v \mathrm{Na}_{2} \mathrm{~S} \times 9 \mathrm{H}_{2} \mathrm{O}$. Additional enrichments used $\mathrm{R}_{2} \mathrm{~A}$ medium and 162 Thermus medium (Degryse et al., 1978), both aerobically with ambient headspace; and Thermotoga ("Toga") medium (Marteinsson et al., 1997) and YPS medium (Marteinsson et al., 2001a) under pure $\mathrm{N}_{2}$ headspace. Growth in enrichments was examined with phase-contrast microscopy (Olympus BX51).

\subsubsection{DNA extraction and PCR reactions in subsurface samples}

To capture microbial cells for DNA extraction and analysis, $250 \mathrm{~mL}$ of sample was filtered through a $47 \mathrm{~mm}, 0.22 \mu \mathrm{m}$ pore size cellulose membrane filter (Millipore Corporation, Bedford, MA, USA) in our laboratory in Reykjavík. The biomass concentration from the filters was determined and the extraction of the chromosomal DNA was performed as described by Marteinsson et al. (2001a). 


\subsubsection{Clone library construction and sequencing}

Polymerase chain reaction (PCR) amplification was performed according to the protocol in Skírnisdóttir et al. (2001) with primers 9F ("5-GAGTTTGATCCTGGCTCAG-3") and 805R ("5-GACTACCAGGGTATCTAATCC-3") (Skírnisdóttir et al., 2001). PCR product was cloned by the TA method using a TOPO TA cloning kit (Invitrogen). Plasmid DNA from single colonies was isolated and sequenced using a BigDye Terminator Cycle Sequencing Ready Reaction Kit on an ABI sequencer (PE Applied Biosystems). Clones were sequenced using the reverse primer $805 \mathrm{R}$. Cloned sequences were analysed and edited by using the program Sequencer 4.8 from ABI. A total of 41 clone sequences were grouped into operational taxonomic units (OTUs) at a threshold of $98 \%$ sequence identity and then aligned by using ClustalW within the MEGA package, version 5.1 (Thompson et al., 1994). In order to check for species identification, sequences were searched against those deposited in GenBank, through the NCBI BLAST (Altschul et al., 1990). Neighbour-joining phylogenetic tree was constructed with MEGA 5.1 (Tamura et al., 2011) using a representative sequence from each OTU and related GenBank sequences.

\subsubsection{Pyrosequencing and analysis}

Two sets of reactions targeting the $\mathrm{v} 4-\mathrm{v} 6$ regions of the archeal 16S rRNA gene were performed using the VAMPS primers (Sogin et al., 2006). First, pyrosequencing of short reads, $70-100 \mathrm{nt}$ of the archeal v6 variable region (primers 958F and 1048R; "5-AATTGGANTCAACGCCGG-3" and "5-CGRCGGCCATGCACCWC-3") in the 16S ribosomal gene was performed with a 454 GS-FLX (Roche) on sample SB4. Cycling conditions included an initial denaturation at $94^{\circ} \mathrm{C}$ for $3 \mathrm{~min} ; 30$ cycles of $94^{\circ} \mathrm{C}$ for $30 \mathrm{~s}, 57-$ $60{ }^{\circ} \mathrm{C}$ for $45 \mathrm{~s}$, and $72^{\circ} \mathrm{C}$ for $1 \mathrm{~min}$; and a final extension at $72^{\circ} \mathrm{C}$ for $2 \mathrm{~min}$. Tags shorter than $60 \mathrm{nt}$ were discarded when trimmed by the GS FLX software. Second, a 454 GS-FLX with Titanium chemistry on samples SB4, SB5 and SB6 for longer reads was preformed with v4v6 Vamps primers (5"YCTACGGRNGGCWGCAG-3" and 5“-CGACRRCCATGCANCACCT-3"). Titanium adaptors A and $B$ were attached to the forward and reverse primers, respectively, along with multiplex identifier (MID) adaptors recommended by Roche to be used in the FLX pyrosequencing. The PCR was performed in a $25 \mu \mathrm{L}$ reaction volume using FastStart High Fidelity polymerase system (Roche, Madison, WI). The PCR program was as follows: $94{ }^{\circ} \mathrm{C}$ $10 \mathrm{~min}, 35$ cycles of $94^{\circ} \mathrm{C}$ for $40 \mathrm{~s}, 52^{\circ} \mathrm{C}$ for $40 \mathrm{~s}, 72^{\circ} \mathrm{C}$ for $60 \mathrm{~s}$ and a final extension step at $72^{\circ} \mathrm{C}$ for $7 \mathrm{~min}$. After the recovery of a PCR product from the DNA the rest of the workflow prior to sequencing was done according to manufacturer instructions for FLX amplicon sequencing using the GS Titanium SV emPCR Lib-A kit (Roche, Madison, WI). With both short and long amplicons, the raw sequences were filtered, trimmed and processed through the Qiime pipeline using the Greenegene database (version 12.1). The first steps included various quality processing including filtering sequences which were under 200 and over $1000 \mathrm{bp}$, containing incorrect primer sequences (> 1 mismatch) and removal of chimera using Decipher (Wright et al., 2011). Sequences were assigned to samples through the MID sequences and clustered into OTUs based on $97 \%$ similarity in the $16 \mathrm{~S}$ rRNA sequences using Uclust and then assigned phylogenetic taxonomy through RDP classifier. OTU sequences were then aligned with PyNast.

\section{Results}

\subsection{Surface sampling and study sites}

At total of 44 surface samples were collected around the island. An overview of the sampling site is shown in Fig. 1. Most of the samples were collected on the southern side of the island where the soil was highly variable ranging from sand to completely vegetated environment with significant interactive effects of bird association including nesting seabirds.

\subsubsection{Viable count of total environmental bacteria and Enterobacteriaceae}

A good visual correlation was found between total bacterial counts with the plate count agar method and growth on R2A media from all samples incubated at $22^{\circ} \mathrm{C}$ (Fig. 3). Positive relationship was also observed between the reduced vegetation or nutrient deficits soils and the number of microorganisms in the samples. The lowest number of bacteria $\left(1 \times 10^{4}-1 \times 10^{5}\right.$ cells g $\left.^{-1}\right)$ was detected in almost pure sand or pumice but the count was significantly higher $\left(1 \times 10^{6}\right.$ $1 \times 10^{9}$ cells $^{-1}$ ) in vegetated soil, sand or pumice with bird droppings (Fig. 3). The number or detection of Enterobacteriaceae in the soil samples showed similar correlation to the viable count and no growth was observed in samples with low numbers of bacteria or $<1 \times 10^{6} \mathrm{cfu} \mathrm{g}^{-1}$ except in one sample (SS-10).

\subsubsection{Counts of total coliforms, faecal coliforms Escherichia coli, and aerobic and anaerobic bacteria growing at $30^{\circ} \mathrm{C}$ and pathogen detection}

A total of 12 soil samples that showed significantly high numbers of environmental bacteria or $>1 \times 10^{6} \mathrm{cfug}^{-1}$ were selected for further testing of viable count of total coliforms, faecal coliforms, Escherichia coli, and aerobic and anaerobic bacteria growing at $30^{\circ} \mathrm{C}$ and detection of pathogens. Additionally samples containing various soil types and with low viable count of total environmental bacteria $<1 \times 10^{6} \mathrm{cfu} \mathrm{g}^{-1}$ were also tested as controls. The re- 


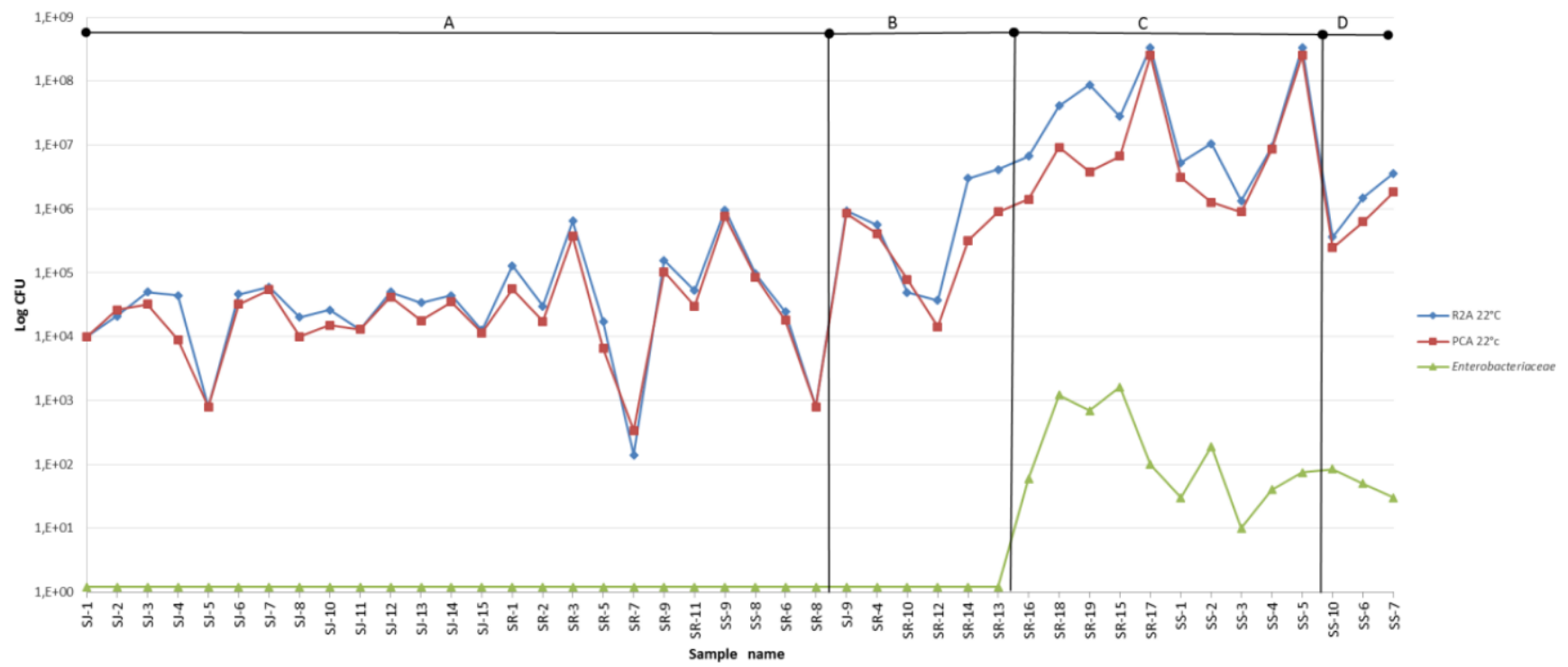

Figure 3. Total bacterial counts with the plate count agar method at $22^{\circ} \mathrm{C}$. The blue diamonds show the total environmental bacterial counts with the plate count agar method and the red squares show the numbers grown on R2A media at $22^{\circ} \mathrm{C}$. The number of Enterobacteriaceae in the soil samples are shown with green triangles. The sample order is oriented according to the appearance of the surface soil, starting with pure sand or pumice and in some cases with tiny vegetation (SR-9, SR-6) or bird droppings (SS-9, SS-8, SR-8) including sample SR-8 (a), partly vegetation including sample SR-13 (b), total vegetation with bird droppings including sample SS-5 (c) and sand with bird droppings including sample SS-10 (d). See Fig. 1 for locations.

sults are summarized in Table 1. Listeria, Campylobacter and Salmonella were not detected in any of the selected samples.

\subsubsection{Soil environment and biogeochemical variables}

Soil nitrogen, carbon and moisture measurements were performed for all samples with sufficient soil quantity for analysis. Measurements of total nitrogen, carbon and water content was performed in 37 samples except in 6 samples that lack totN\% measurements. Seven samples could not be measured (Table 1). Average totN\% measurements were similar in SJ and SR samples, 0.01 and 0.02 , respectively, but SS samples containing bird droppings were at least 60 times higher at 0.68. Average totC\% was also highest in SS samples at 4.68 and SJ and SR samples were 1.17 and 2.74, respectively. Average water content in SJ, SR and SS samples were 0.34, 0.91 and 0.61 , respectively.

\subsubsection{Multivariate analysis of environmental parameters}

In order to capture the niche similarities between sampling sites, multivariate NMDS analysis was performed based on measurements of environmental parameters. The analysis showed that the SS samples are separated from other samples while the SR and SJ samples overlap. Samples SR15-17 are well separated from all other samples which is due to their higher load of Enterobacteriaceae, total viable counts and higher water content compared to other sampling

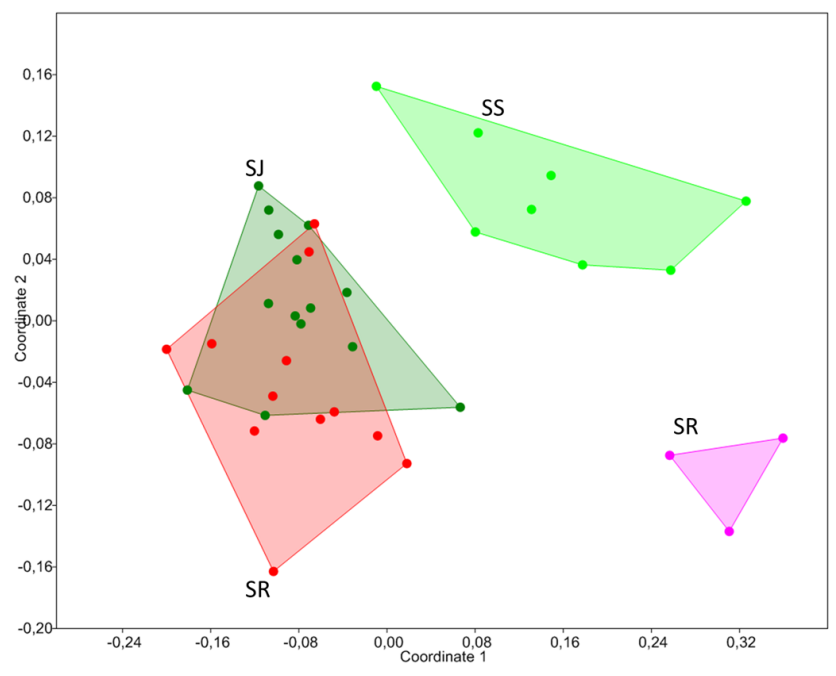

Figure 4. Non-metric multidimensional scaling, Euclidean distances. Environmental parameters included in analysis: temperature, total carbon, total nitrogen, water content, total microbial count of PCA and counts of Enterobacteriaceae. SS samples (3-10) in light green (sand or pumice with bird droppings), SJ samples (17 and 10-15) in dark green (pure sand or pumice) and SR (1-12) samples in red (partly vegetated and non-vegetated area) and SR (15-17) in purple (vegetated).

sites (Fig. 4). For selected samples, more environmental data were recorded (NEE, Re., GPP, PAR, Ts05, Ts10, Cov.) and were used as a base for another sub-NMDS analysis which 
Table 1. Viable count of total coliforms, faecal coliforms, Escherichia coli, and aerobic and anaerobic bacteria growing at $30^{\circ} \mathrm{C}$ and detection of pathogens on different media (PCA, R2A, VRBGA).

\begin{tabular}{|c|c|c|c|c|c|c|c|c|c|c|c|c|}
\hline \multirow[t]{2}{*}{ Soil no. } & \multirow[t]{2}{*}{$\mathrm{T}^{\circ}(\mathrm{C})$} & \multirow{2}{*}{$\begin{array}{r}\mathrm{PCA} 22^{\circ} \mathrm{C} \\
\left(\mathrm{cfug}^{-1}\right)\end{array}$} & \multirow{2}{*}{$\begin{array}{r}\mathrm{R} 2 \mathrm{~A} 22^{\circ} \mathrm{C} \\
\left(\mathrm{cfug} \mathrm{g}^{-1}\right)\end{array}$} & \multirow{2}{*}{$\begin{array}{r}\text { VRBGA } \\
37^{\circ} \mathrm{C} \\
\left(\mathrm{cfu} \mathrm{g}^{-1}\right)\end{array}$} & \multicolumn{2}{|c|}{$\mathrm{CFU} 30^{\circ} \mathrm{C}$} & \multirow{2}{*}{$\begin{array}{r}\text { Coliforms } \\
\text { /MPN }\end{array}$} & \multirow{2}{*}{$\begin{array}{r}\text { Faecal } \\
\text { coli } \\
\\
\text { /MPN }\end{array}$} & \multirow{2}{*}{$\begin{array}{l}\text { E.coli } \\
\text { /MPN }\end{array}$} & \multirow{2}{*}{$\begin{array}{r}\text { totN } \\
(\% \text { of } d w)\end{array}$} & \multirow{2}{*}{$\begin{array}{r}\text { totC } \\
(\% \text { of } d w)\end{array}$} & \multirow[t]{2}{*}{ GWC } \\
\hline & & & & & Aerobic & Anaerobic & & & & & & \\
\hline SJ-1 & 21.2 & $1.0 \times 10^{4}$ & $1.0 \times 10^{4}$ & 0 & nd & nd & nd & nd & nd & 0.0095 & 0.24 & 0.20 \\
\hline $\mathrm{SJ}-2$ & 30.6 & $2.6 \times 10^{4}$ & $2.1 \times 10^{4}$ & 0 & nd & nd & nd & nd & nd & 0.0110 & 0.28 & 0.18 \\
\hline SJ-3 & 25.7 & $3.2 \times 10^{4}$ & $5.0 \times 10^{4}$ & 0 & nd & nd & nd & nd & nd & 0.0280 & 0.43 & 0.15 \\
\hline SJ-4 & 27.0 & $9.0 \times 10^{3}$ & $4.4 \times 10^{4}$ & 0 & nd & nd & nd & nd & nd & 0.0020 & 0.18 & 0.14 \\
\hline SJ-5 & 23.1 & $8.0 \times 10^{2}$ & $8.0 \times 10^{2}$ & 0 & nd & nd & nd & nd & nd & 0.0010 & 0.09 & 0.09 \\
\hline SJ-6 & 26.5 & $3.2 \times 10^{4}$ & $4.6 \times 10^{4}$ & 0 & nd & nd & nd & nd & nd & 0.0030 & 0.20 & 0.30 \\
\hline SJ-7 & 27.0 & $5.4 \times 10^{4}$ & $6.0 \times 10^{4}$ & 0 & nd & nd & nd & nd & nd & nd & 2.49 & 0.13 \\
\hline SJ-8 & 26.8 & $1.0 \times 10^{4}$ & $2.0 \times 10^{4}$ & 0 & nd & nd & nd & nd & nd & nd & 9.06 & 1.37 \\
\hline SJ-9 & 25.9 & $8.5 \times 10^{5}$ & $9.3 \times 10^{5}$ & 0 & nd & nd & nd & nd & nd & nd & nd & nd \\
\hline SJ-10 & 26.0 & $1.5 \times 10^{4}$ & $2.6 \times 10^{4}$ & 0 & nd & nd & nd & nd & nd & 0.0180 & 0.99 & 0.84 \\
\hline SJ-11 & 33.0 & $1.3 \times 10^{4}$ & $1.3 \times 10^{4}$ & 0 & nd & nd & nd & nd & nd & nd & 0.38 & 0.17 \\
\hline SJ-12 & 27.0 & $4.2 \times 10^{4}$ & $5.0 \times 10^{4}$ & 0 & $3.1 \times 10^{2}$ & $1.0 \times 10^{1}$ & $3.0 \times 10^{0}$ & $3.0 \times 10^{0}$ & $3.0 \times 10^{0}$ & 0.0090 & 0.36 & 0.34 \\
\hline SJ-13 & 31.0 & $1.79 \times 10^{4}$ & $3.4 \times 10^{4}$ & 0 & $8.2 \times 10^{2}$ & $1.0 \times 10^{1}$ & $3.0 \times 10^{0}$ & $3.0 \times 10^{0}$ & $3.0 \times 10^{0}$ & 0.0165 & 1.00 & 0.30 \\
\hline SJ-14 & 29.5 & $3.5 \times 10^{4}$ & $4.4 \times 10^{4}$ & 0 & nd & nd & nd & nd & nd & 0.0030 & 0.33 & 0.28 \\
\hline SJ-15 & 32.0 & $1.14 \times 10^{4}$ & $1.26 \times 10^{4}$ & 0 & nd & nd & nd & nd & nd & nd & 0.41 & 0.29 \\
\hline SR-1 & 15.5 & $5.6 \times 10^{4}$ & $9 \times 10^{5}$ & 0 & nd & nd & nd & nd & nd & 0.0060 & 0.21 & 0.14 \\
\hline SR-2 & 21.0 & $1.73 \times 10^{4}$ & $0 \times 10^{4}$ & 0 & nd & nd & nd & nd & nd & 0.0060 & 0.08 & 0.14 \\
\hline SR-3 & 21.0 & $3.7 \times 10^{5}$ & $4 \times 1$ & 0 & nd & nd & nd & nd & nd & 0.0030 & 1.28 & 0.99 \\
\hline SR-4 & 21.0 & $\times 1$ & $5.6 \times 1$ & 0 & $2.2 \times 10^{3}$ & $1.5 \times 10^{2}$ & $3.0 \times 10^{0}$ & $3.0 \times 10^{0}$ & $3.0 \times 10^{0}$ & 0.0120 & 0.73 & 0.49 \\
\hline SR-5 & 22.4 & $5 \times 10^{3}$ & $1.71 \times 10^{4}$ & 0 & nd & nd & nd & nd & nd & 0.0210 & 2.42 & 0.23 \\
\hline SR-6 & 22.3 & $1.8 \times 10^{4}$ & $2.43 \times 10^{4}$ & 0 & nd & nd & nd & nd & nd & 0.0030 & 0.18 & 0.18 \\
\hline SR-7 & 24.7 & $3.4 \times 10^{2}$ & $1.4 \times 10^{2}$ & 0 & nd & nd & nd & nd & nd & 0.0340 & 0.18 & 0.18 \\
\hline SR-8 & 25.3 & $8.0 \times 10^{2}$ & $8.0 \times 10^{2}$ & 0 & nd & nd & nd & nd & nd & 0.0015 & 0.24 & 0.24 \\
\hline SR-9 & 30.7 & $1.04 \times 10^{5}$ & $1.57 \times 10^{5}$ & 0 & $1.2 \times 10^{2}$ & $1.0 \times 10^{1}$ & $3.0 \times 10^{0}$ & $3.0 \times 10^{0}$ & $3.0 \times 10^{0}$ & nd & 0.35 & 0.22 \\
\hline SR-10 & 29.7 & $7.9 \times 10^{4}$ & $4.9 \times 10^{4}$ & 0 & nd & nd & nd & nd & nd & 0.0165 & 0.32 & 0.30 \\
\hline SR-11 & 22.0 & $3.0 \times 10^{4}$ & $5.3 \times 10^{4}$ & 0 & nd & nd & nd & nd & nd & 0.0030 & 0.61 & 0.59 \\
\hline SR-12 & 24.0 & $1.43 \times 10^{4}$ & $3.7 \times 10^{4}$ & 0 & nd & nd & nd & nd & nd & nd & 0.25 & 0.24 \\
\hline SR-13 & 26.3 & $9.0 \times 10^{5}$ & $4.1 \times 10^{6}$ & $2.2 \times 10^{2}$ & nd & nd & nd & nd & nd & nd & nd & nd \\
\hline SR-14 & 23.7 & $3.2 \times 10^{5}$ & $3.0 \times 10^{6}$ & 0 & nd & nd & nd & nd & nd & nd & nd & nd \\
\hline SR-15 & 22.7 & $6.7 \times 10^{6}$ & $2.8 \times 10^{7}$ & $1.63 \times 10^{3}$ & $5.8 \times 10^{4}$ & $3.0 \times 10^{1}$ & $1.5 \times 10^{2}$ & $9.3 \times 10^{1}$ & $9.3 \times 10^{1}$ & 0.0210 & 6.14 & 2.82 \\
\hline SR-16 & 25.0 & $1.42 \times 10^{6}$ & $6.7 \times 10^{6}$ & $1.2 \times 10^{2}$ & $8.8 \times 10^{4}$ & $1.9 \times 10^{3}$ & $3.0 \times 10^{0}$ & $3.0 \times 10^{0}$ & $3.0 \times 10^{0}$ & 0.0690 & 14.22 & 3.99 \\
\hline SR-17 & 23.0 & $1.0 \times 10^{8}$ & $1.0 \times 10^{8}$ & $2.0 \times 10^{2}$ & $1.4 \times 10^{4}$ & $1.0 \times 10^{1}$ & $9.3 \times 10^{2}$ & $9.3 \times 10^{2}$ & $9.3 \times 10^{2}$ & 0.0420 & 13.87 & 2.85 \\
\hline SR-18 & nd & $9.1 \times 10^{6}$ & $4.1 \times 10^{7}$ & $2.42 \times 10^{3}$ & $7.6 \times 10^{4}$ & $4.5 \times 10^{2}$ & $3.0 \times 10^{0}$ & $3.0 \times 10^{0}$ & $3.0 \times 10^{0}$ & nd & nd & nd \\
\hline SR-19 & 27.9 & $3.8 \times 10^{6}$ & $8.7 \times 10^{7}$ & $6.92 \times 10^{2}$ & $4.1 \times 10^{3}$ & $5.0 \times 10^{1}$ & $3.0 \times 10^{0}$ & $3.0 \times 10^{0}$ & $3.0 \times 10^{0}$ & nd & nd & nd \\
\hline SS-1 & 27.1 & $3.1 \times 10^{6}$ & $5.3 \times 10^{6}$ & $6.0 \times 10^{1}$ & $3.7 \times 10^{4}$ & $1.3 \times 10^{2}$ & $2.3 \times 10^{1}$ & & $9.0 \times 10^{0}$ & nd & nd & nd \\
\hline SS-2 & 26.0 & $1.26 \times 10^{6}$ & & & & & & & $3.0 \times 10^{0}$ & nd & nd & nd \\
\hline SS-3 & 26.7 & & & $2.0 \times 10^{1}$ & $1.4 \times 10^{3}$ & $4.0 \times 10^{1}$ & $9.3 \times 10^{2}$ & $9.3 \times 10^{2}$ & $9.3 \times 10^{2}$ & 0.6785 & 7.30 & 0.98 \\
\hline SS-4 & 25.7 & $8.5 \times 10^{6}$ & $9.3 \times 10^{6}$ & $4.0 \times 10^{1}$ & $1.0 \times 10^{4}$ & $5.0 \times 10^{1}$ & $4.3 \times 10^{1}$ & $4.3 \times 10^{1}$ & $4.3 \times 10^{1}$ & 0.6785 & 14.90 & 1.56 \\
\hline SS-5 & 28.4 & $2.52 \times 10^{8}$ & $3.37 \times 10^{8}$ & $7.5 \times 10^{1}$ & $1.4 \times 10^{4}$ & $1.0 \times 10^{1}$ & $9.3 \times 10^{2}$ & $9.3 \times 10^{2}$ & $9.3 \times 10^{2}$ & 0.6785 & 8.10 & 1.00 \\
\hline SS-6 & 26.5 & $6.3 \times 10^{5}$ & $1.49 \times 10^{6}$ & $5.0 \times 10^{1}$ & $4.6 \times 10^{3}$ & $3.0 \times 10^{2}$ & $3.0 \times 10^{0}$ & $3.0 \times 10^{0}$ & $3.0 \times 10^{0}$ & 0.6785 & 1.70 & 0.45 \\
\hline SS-7 & 26.5 & $1.82 \times 10^{6}$ & $3.6 \times 10^{6}$ & $3.0 \times 10^{1}$ & $3.0 \times 10^{4}$ & $2.0 \times 10^{4}$ & $9.3 \times 10^{2}$ & $9.3 \times 10^{2}$ & $9.3 \times 10^{2}$ & 0.6785 & 2.30 & 0.28 \\
\hline SS-8 & 32.3 & $8.5 \times 10^{4}$ & $9.6 \times 10^{4}$ & 0 & nd & nd & nd & nd & nd & 0.6785 & 0.60 & 0.19 \\
\hline SS-9 & 25.5 & $7.6 \times 10^{5}$ & $9.6 \times 10^{5}$ & 0 & nd & nd & nd & nd & nd & 0.6785 & 2.10 & 0.29 \\
\hline SS-10 & 25.3 & $2.47 \times 10^{5}$ & $3.6 \times 10^{5}$ & $8.4 \times 10^{1}$ & $3.3 \times 10^{3}$ & $6.2 \times 10^{2}$ & $4.6 \times 10^{2}$ & $4.6 \times 10^{2}$ & $4.6 \times 10^{2}$ & 0.6785 & 0.50 & 0.15 \\
\hline
\end{tabular}

nd: not determined, CFU: colony-forming unit, MPN: most probable number, totN (\% of dw): percentage of nitrogen, totC (\% of dw): percentage of carbon, GWC: soil gravimetric water content, $T^{\circ}(\mathrm{C})$ : surface temperature.

confirmed previous analysis and clustered the most vegetated samples together (data not shown). Table 2 shows the $\mathrm{CO}_{2}$ flux measurements. Other SR samples were gathered together, except for SR-3 which is also a great distance geographically from the other SR samples.

\subsection{Subsurface sampling}

\subsubsection{Sampling and temperature data}

The temperature was measured along the drill hole at $1 \mathrm{~m}$ intervals from the surface down to the bottom at $178 \mathrm{~m}$ with a borehole temperature meter. The temperature measurements are shown in Fig. 5 in relation to the depth in the drill hole. The maximum temperature was $130^{\circ} \mathrm{C}$ at $95 \mathrm{~m}$ depth and the bottom temperature was $40^{\circ} \mathrm{C}$ at $178 \mathrm{~m}$ depth. The temperature was $54.8 \pm 0.1{ }^{\circ} \mathrm{C}$ at $168 \mathrm{~m}$ depth and remained sta- 
Table 2. $\mathrm{CO}_{2}$ flux measurements from selected samples.

\begin{tabular}{lrrrrr}
\hline & $\begin{array}{r}\mathrm{NEE} \\
(\mu \mathrm{mol} \mathrm{CO} 2 \\
\left.\mathrm{m}^{-2} \mathrm{~s}^{-1}\right)\end{array}$ & $\begin{array}{r}\text { Respiration } \\
\left(\mu \mathrm{mol} \mathrm{CO} \mathrm{CO}_{2}\right. \\
\left.\mathrm{m}^{-2} \mathrm{~s}^{-1}\right)\end{array}$ & $\begin{array}{r}\mathrm{GPP} \\
\left(\mu \mathrm{mol} \mathrm{CO} \mathrm{CO}_{2}\right. \\
\left.\mathrm{m}^{-2} \mathrm{~s}^{-1}\right)\end{array}$ & $\begin{array}{r}(\mu \mathrm{mol} \text { photons } \\
\left.\mathrm{m}^{-2} \mathrm{~s}^{-1}\right)\end{array}$ & $\begin{array}{r}\text { Vegetation } \\
\text { cover } \\
(\%)\end{array}$ \\
\hline SR-1 & -1.59 & 0.26 & -1.85 & 761 & 90 \\
SR-3 & 0.06 & 0.1 & -0.04 & 802 & 1 \\
SR-5 & 0.05 & 0.05 & 0 & 1270 & 0 \\
SR-7 & 0.15 & 0.15 & 0 & 870 & 0 \\
SR-9 & 0.01 & 0.01 & 0 & 1170 & 0 \\
SR-11 & 0.02 & 0.02 & 0 & 800 & 0 \\
SR-15 & -0.02 & 0.02 & -0.04 & 854 & 60 \\
SR-16 & -0.18 & 0.4 & -0.58 & 687 & 100 \\
SR-19 & -0.07 & 0.27 & -0.34 & 1209 & 100 \\
\hline
\end{tabular}

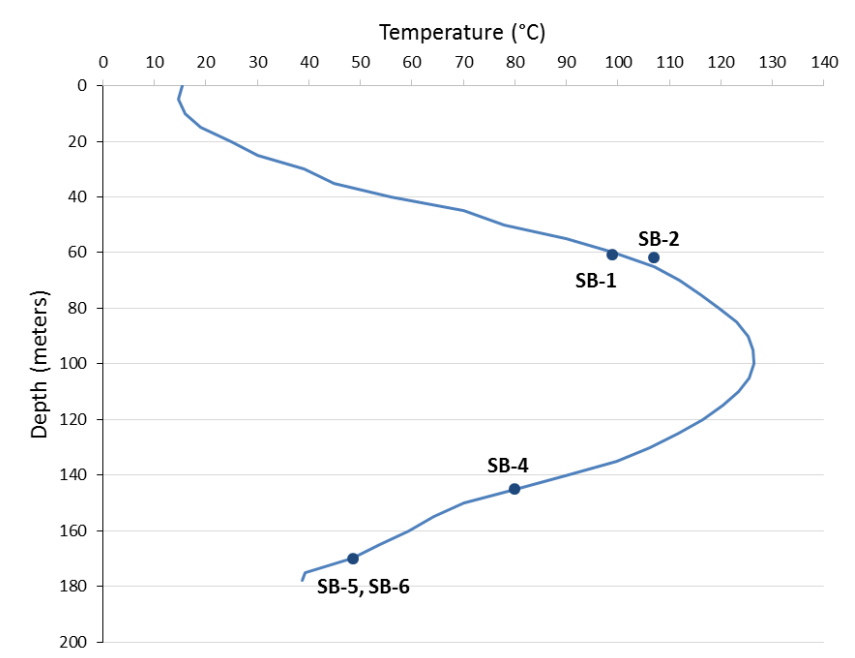

Figure 5. Temperatures at $5 \mathrm{~m}$ intervals along the drill hole, from the surface down to the bottom at $178 \mathrm{~m}$. The circles show the depth and temperature of the SB samples.

ble over $21 \mathrm{~h}$. About $250 \mathrm{~mL}$ were sampled at each depth as follows, $57 \mathrm{~m}$ (SB1) and $58 \mathrm{~m}$ depth (SB2), both samples at $100^{\circ} \mathrm{C}$, at $145 \mathrm{~m}$ depth (SB4) at $80^{\circ} \mathrm{C}$, at $168 \mathrm{~m}$ (SB5) and $170 \mathrm{~m}$ depth (SB6) both samples at $54-55^{\circ} \mathrm{C}$. The $\mathrm{pH}$ was slightly above 8.0 in the samples, and the salinity was above sea salinity at around $3.7 \%$.

\subsubsection{Enrichment cultures of subsurface samples}

No growth could be observed after about 6 weeks of incubation in any of the enrichments incubated at 40,60 and $80^{\circ} \mathrm{C}$.

\subsubsection{DNA extraction, PCR reactions and clone library construction}

Very small pellets of undetermined biomass were obtained from all SB samples, and DNA concentration was extremely low. PCR amplification products were achieved from SB4, SB5 and SB6 with both universal bacterial and archaeal primers. Library construction was successful with clones containing bacterial 16S rRNA genes that were amplified in samples SB5 and SB6 and with archaeal genes in sample SB6.

\subsubsection{Subsurface diversity analysis, clonal and next-generation sequencing}

Three approaches were used to assess the bacterial and archeal taxa composition in the samples: partial sequencing of cloned 16S rRNA fragments, pyrosequencing of short fragment of the v6 region and pyrosequencing of a longer fragment of v4-v6 region. Clone libraries of the 40 archaeal 16S rRNA genes (500 bp) in sample SB6 showed high homology $(99 \%)$ to uncultured subsurface archaea-related sequences (Genbank accession DQ354739.1) from subsurface water of the Kalahari Shield, South Africa by BLAST method. All the clones were dominated by this one sequence except two clones which showed high homology to uncultured subsurface archaea-related sequences, DQ988142 and AB301979.1, from methane cycling in subsurface marine sediments and from hydrothermal sediments at the Yonaguni Knoll IV hydrothermal field in the southern Okinawa Trough, respectively. Clone libraries of the bacterial 16S rRNA genes in sample SB5 and SB6 and their closest known relatives are presented in neighbour-joining tree of sequences which is shown in Fig. 6. The SB4 v6 library consists mostly or $94.5 \%$ of a single taxon affiliated with genus $A r$ chaeoglobus from the phylum Euryarchaeota (18.08724.000 short sequences), $0.1 \%$ was affiliated to Methanomicrobia, $3.5 \%$ to unassignable Euryarchaeota, $0.1 \%$ to Crenarchaeota and $1.8 \%$ to undefined archaea. The longer reads of the v4v6 regions with Titanium chemistry on samples SB5 and SB6 showed the vast majority of pyrosequencing reads taxonomically affiliated with one taxa, Methanobacteriales, SB6 $76.5 \%$ (5121 sequences) and SB5 84.2\% (8307 sequences). The results are summarized in Fig. 7. 


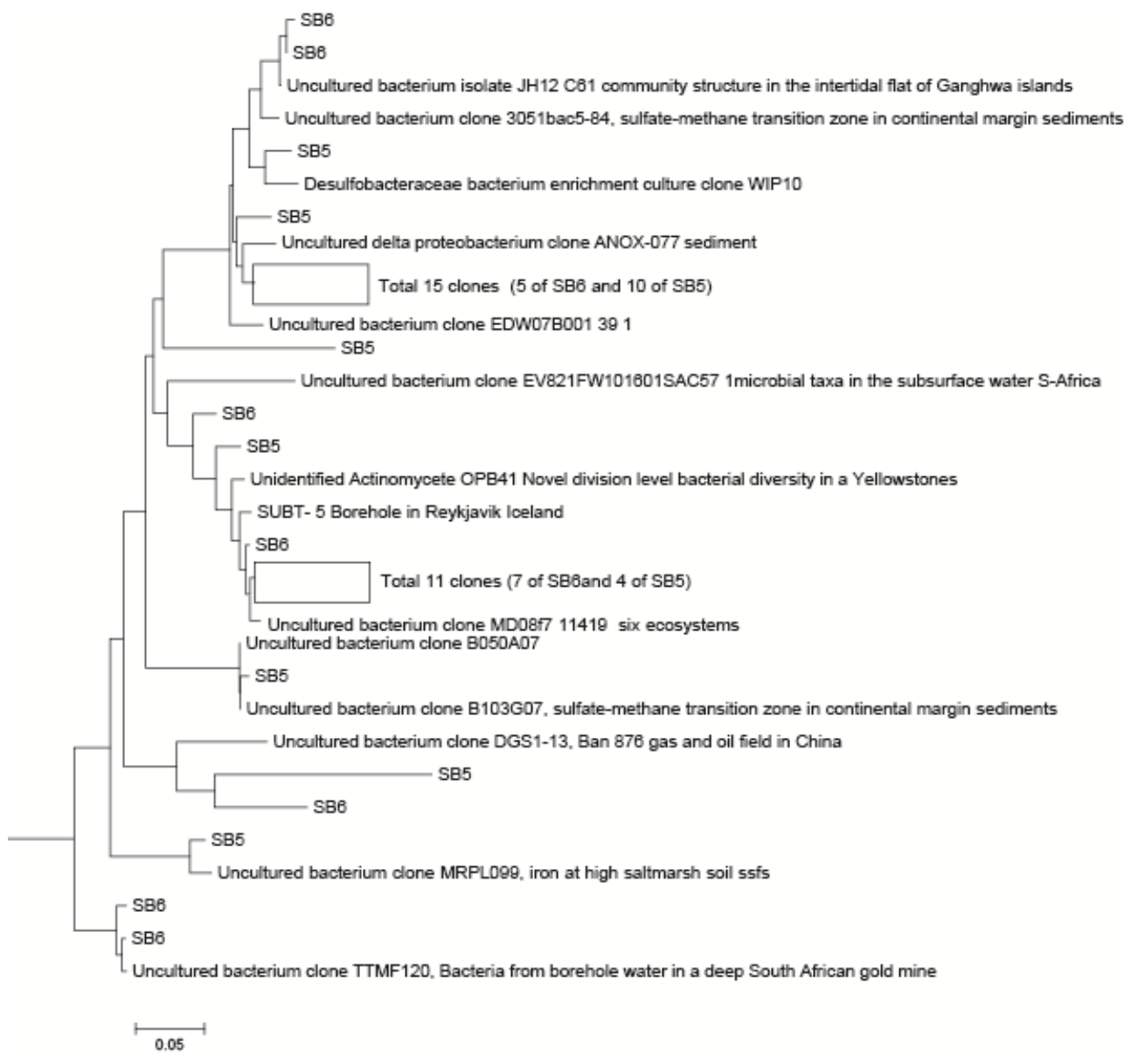

Figure 6. Neighbour-joining tree of sequences from the 16S rRNA clone libraries, databases showing phylogenetic relationships. The scale bar represents the expected percentage of substitutions per nucleotide position, and a marine Crenarchaeon was used as outgroup. The cluster in uncultured delta Proteobacterium clone ANOX-077 represents 11 clones with $99 \%$ sequence similarity (5 SB6 and 10 SB5 from the borehole). The cluster in uncultured bacterium clone MD08f7 11 clones with $99 \%$ sequence similarity (7 SB6 and 5 SB5 from the borehole).

\section{Discussion}

\subsection{Surface soil samples}

Before sampling, surface samples were classified into three types according to their visual appearance in the field: pumice soil with bird droppings (10 SS samples), pure pumice soil (15 SJ samples) and mixed (19 SR samples). The SR samples were soil that were totally or partly vegetated or pure pumice. They were all collected inside of a defined area used for activity measurements of soil (Magnússon et al., 2014; Sigurdsson and Magnússon, 2010). Ecosystem respiration $(\mathrm{Re})$ was measured inside these zones in order to investigate soil properties and surface cover of vascular plants. These zones were distributed among the juvenile communities of the island, inside and outside a seagull colony established on the island (Sigurdsson, 2009). As shown with an overview of the sampling sites on the island of Surtsey (Fig. 1), most of the surface samples were collected on the southern side of the island, in the same area as seagull (Larus spp.) colony was established and consequently with high vegetation, but also outside that area which contained less vegetation. The content of organic matter such as carbon and nitrogen is low in the soil of Surtsey where there is no vegetation, but normally high in vegetated soils with bird droppings. In the early stage of primary succession on the island, the plant nutrients are retained within the soil system and within microorganisms. We observed a significant correlation between the amount of organic matter in soils and the number of heterotrophic environmental microorganisms grown on two different media at $22^{\circ} \mathrm{C}$, and the lowest number of bacteria $\left(1 \times 10^{4}-1 \times 10^{5}\right.$ cells $\left.^{-1}\right)$ was measured in pure pumice; however, the count was significant higher $\left(1 \times 10^{6}-1 \times 10^{9}\right.$ cells $\left.\mathrm{g}^{-1}\right)$ in vegetated soil or pumice with bird droppings (Fig. 3). Moreover, the number of bacteria belonging to Enterobacteriaceae in all the soil samples showed a strong correlation to higher counts of total environmental bacteria in samples containing high organic matter. Samples (SS) encompassing bird droppings also contained 


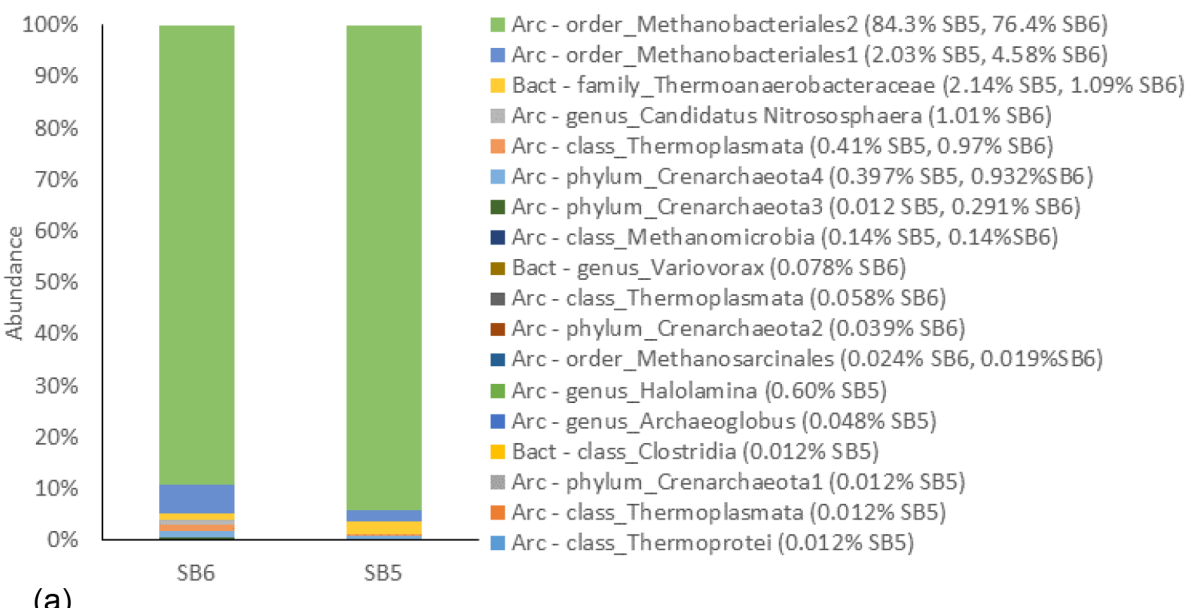

(a)
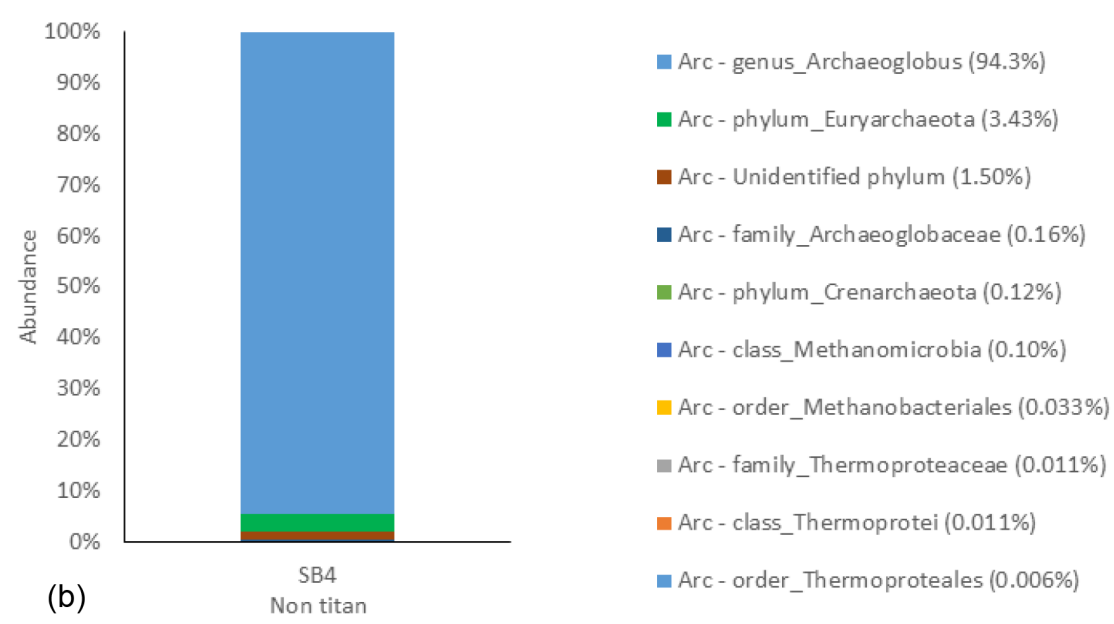

Figure 7. Sequencing results of the $16 \mathrm{~S}$ rRNA gene with a next-generation sequencing method. (a) The longer reads of the v4-v6 regions with Titanium pyrosequencing on samples SB5 and SB6 (from the borehole). (b) Pyrosequencing of short fragment of the v6 region of the SB4 (from the borehole) v6 library. The columns and the colours show the percentage of each major taxon (see text and percentage of each major and minor taxon on the right).

Enterobacteriaceae but in low numbers $\left(10^{1}\right.$ cells g $\left.^{-1}\right)$. Correlation of high numbers of microbes to organic matter can be anticipated as input of organic matter from plant production supports growth of microbial heterotrophic soil microbial communities (Fenchel et al., 2012; Roesch et al., 2007; Schlesinger, 1997; Whitman et al., 1998). It has also been demonstrated that a high number of viable counts of environmental bacteria and high organic matter could signify a more diverse groups of bacteria such as coliforms, faecal coliforms, Escherichia coli, and aerobic and anaerobic bacteria growing at $30^{\circ} \mathrm{C}$, and even pathogenic bacteria (Girdwood et al., 1985; Pommepuy et al., 1992). Consequently, samples in this study that showed significantly high number of environmental bacteria and few other samples with low bacterial counts were selected for further investigation to measure coliforms and the presence of pathogenic microbes such as Listeria, Campylobacter and Salmonella.

Interestingly, the results in this study showed relatively little variance among soil types. The controls or pure pumice samples showed little growth by any culturing method tested as expected but soils with some vegetation and bird droppings revealed also low cell counts apart from aerobic bacteria growing at $30^{\circ} \mathrm{C}$. It is noteworthy that despite high vegetation and seagull activity, we measured low numbers of faecal coliforms except in one sample (SR-17) and a few other samples with bird droppings but none of the samples contained any of the pathogens that were tested for. This suggests that the coliforms and faecal coliforms cannot survive long in the soil (Avery et al., 2004; Sun et al., 2006).

Our classification of sample types by using multivariate NMDS analysis based on our results is in agreement with the 
visual classification of sample types to a certain extent. The analysis showed that all the SS samples were clearly separated from the other samples while the other two types of soil samples, SR and SJ, were gathered into one big group that could be divided into two smaller sub groups and one small group completely separate. This unique group (SR) contained samples that were highly vegetated. The vegetated samples, i.e. SR-14 to SR-19, were distinct and different from all other samples due to a higher load of Enterobacteriaceae, total viable counts, higher percentage of carbon, nitrogen and water content compared to other sampling sites (Fig. 4, Table 1). Moreover, by taking into account data only from samples (all SR samples) collected for ecosystem respiration (Re), they could be divided mainly into two groups reflecting the soil properties or vegetation, inside and outside the seagull colony. SR-16, 15, and 19 were clustered inside the main seagull colony on the southern part of the island were SR-7, 11, 5 and 9 are clustered just beside the main seagull colony or south-east part of the island, while the two most dissimilar samples SR-3 and SR-1 were collected far away from the seagull colony, on the northern part of the island.

\subsection{Subsurface samples}

Access to the deep biosphere in a remote neo-volcanic island is extremely unique. We were able for the first time to collect hot subsurface samples deep in the centre of a volcanic island, created by a series of volcanic eruption only 42 years after the eruption break. Additionally, as reported for geothermal boreholes in Reykjavík, the surface of the drill hole in Surtsey can be regarded as a window to the deep subsurface biosphere of the island (Marteinsson et al., 2001a). This window has been open for 30 years before our sampling in 2009 as the borehole was finished in August 1979 (Jakobsson and Moore, 1982). The purpose of the drill hole was to obtain a core for studying the structure of the island and the hydrothermal alteration of the tephra formed during the Surtsey eruption (Ólafsson and Jakobsson, 2009). The drill site is located on the edge of the Surtur tephra crater at $58 \mathrm{~m}$ above sea level with a total depth of $181 \mathrm{~m}$. Several temperature measurements have been taken along the depth of the drill hole since the drilling and it appears that the hole has cooled since 1980 (Ólafsson and Jakobsson, 2009). Our temperature measurements along the drill hole at $1 \mathrm{~m}$ intervals from the surface down to the bottom at $180 \mathrm{~m}$ showed drastic temperature changes compared to previous measurements. Our highest temperature measurement was $126.5^{\circ} \mathrm{C}$ which is about $14^{\circ} \mathrm{C}$ lower than maximal heat reported in 1980 and $3.5^{\circ} \mathrm{C}$ lower than in 2004 (Ólafsson and Jakobsson, 2009). In our study we were able to record the temperature with a temperature logger for $21 \mathrm{~h}$ at $15 \mathrm{~min}$ intervals at $168 \mathrm{~m}$ depth in the borehole, and the temperature proved to be remarkably stable at this depth at $54.8 \pm 0.1{ }^{\circ} \mathrm{C}$. This could indicate a very minor cooling effect of cold seawater in the system. To our knowledge, this is the first long-term temperature measurements in the borehole of Surtsey. Such deep environments with temperatures below $100^{\circ} \mathrm{C}$ and a high temperature barrier $\left(130^{\circ} \mathrm{C}\right)$ overhead are ideal conditions for the growth of extreme microorganisms. The high temperature and the casing of the borehole down to $165 \mathrm{~m}$ isolates the bottom environment from the upper layers or surface microorganisms (Ólafsson and Jakobsson, 2009). The high sterilizing temperature atop the borehole suggest indigenous subterrestrial microbiota that have probably disseminated from the below faults and cracks of the seafloor in a similar manner as has been reported for other various subterrestrial environments, geothermal boreholes in Reykjavík (Marteinsson et al., 2001a), fresh water hydrothermal vent cones in Eyjafjörður (Marteinsson et al., 2001b) and in subglacial lakes on Vatnajökull (Marteinsson et al., 2013). Furthermore, our results on the microbial diversity support such deep indigenous subterrestrial microbiota speculations as our 16S rRNA gene sequence showed only similarity to uncultivated taxon originated from the deep biosphere. Our archaeal clone libraries of the 40 archaeal 16S rRNA genes in sample SB6 at $172 \mathrm{~m}$ depth showed high homology (99\%) to uncultured subsurface archaea-related sequences from subsurface water of the Kalahari Shield, South Africa by BLAST method (Genbank accession DQ354739.1). All the clones were dominated by this one sequence except two clones which showed high homology to uncultured subsurface archaea-related sequences from methane cycling in subsurface marine sediments and from a hydrothermal sediments at the Yonaguni Knoll IV hydrothermal field in the southern Okinawa Trough, DQ988142 and AB301979.1, respectively. The bacterial clone libraries obtained from samples SB5 and SB6 showed high diversity as is presented in a neighbour-joining tree of sequences in Fig. 6. All these clones could not be affiliated with high homology to any cultivated bacteria and their closest relatives were uncultivated bacterium clones from various subsurfaces or sediments. Interestingly, a few clones (12 clones) showed homology to clone SUBT5 from geothermal boreholes in Reykjavík (Marteinsson et al., 2001a). Similarly, with our deep pyrosequencing results, the SB4 v6 library consists mostly (at $94.5 \%$ ) of a single taxon affiliated with genus Archaeoglobus from the phylum Euryarchaeota, $0.1 \%$ was affiliated to Methanomicrobia, 3.5 to unassignable Euryarchaeota, 0.1 to Crenarchaeota and $1.8 \%$ to archaea (Fig. 7). It is noteworthy that Archaeoglobus species has been isolated from various marine environments and has optimum growth temperature at $80^{\circ} \mathrm{C}$ or at the same temperature measured at $145 \mathrm{~m}$ depth of the borehole (SB4) (Huber et al., 1995; Stetter et al., 1993; Stetter et al., 1987). The longer reads of the v4-v6 regions with Titanium chemistry on samples collected at $172 \mathrm{~m}$ depth at $55^{\circ} \mathrm{C}$, SB5 and SB6, showed that the vast majority of pyrosequencing reads were taxonomically affiliated with one taxa Methanobacteriales, $84.2 \%$ and $76.5 \%$, respectively (Fig. 7). Interestingly, many methanogens grow at similar temperatures as found 
in these sample depths. Finally, despite various enrichment conditions and media, we were not able to enrich any microbes with our culture techniques. This may suggest that we have not been able to create the right physical growth conditions and/or use the right media composition for developing growth.

\section{Conclusions}

We have explored for the first time microbial colonization in diverse surface soils and the influence of associate vegetation and birds on viable counts of environmental bacteria at the surface of Surtsey. The number of faecal bacteria correlated to the higher total number of environmental bacteria and type of soil but no pathogenic microbes were detected in any sample tested. We were able for the first time to collect hot subsurface samples deep in the centre of this volcanic island and record the temperature for $21 \mathrm{~h}$ at $168 \mathrm{~m}$ depth. Both uncultivated bacteria and archaea were found in the subsurface samples collected below $145 \mathrm{~m}$. The microbial community at $54^{\circ} \mathrm{C}$ and $172 \mathrm{~m}$ depth was dominant, with diverse bacteria and a homogeny archaeal community of Methanobacteriales, while the archaeal community at $145 \mathrm{~m}$ depth and $80^{\circ} \mathrm{C}$ was dominated by Archaeoglobus-like sequences. The subsurface microbial community in Surtsey may be regarded as indigenous subterrestrial microbiota as both bacteria and archaea showed low affiliation to any known microbiota and there is a high temperature barrier $\left(130^{\circ} \mathrm{C}\right)$ overhead.

Acknowledgements. The authors thank Á. R. Rúnarsson and S. Magnússun for their technical contribution, and the scientific team of the Surtsey expedition in 2009, especially B. Magnússon and E. S. Hansen. We would also like to thank S. Jakobsson for helpful discussions and Náttúrufræðistofnun Íslands for the topographic map of Surtsey. Special thanks are to S. Guðbjörnsson for providing a temperature logger from Star Oddi. Many thanks are also due to the Matís staff working in the division of analysis and consulting. This work was partly financed by preliminary grant from The Icelandic Centre for Research (RANNIS) and the European Union program MaCuMBA (grant agreement 311945).

Edited by: B. Magnússon

\section{References}

Altschul, S. F., Gish, W., Miller, W., Myers, E. W., and Lipman, D. J.: Basic local alignment search tool, J. Mol. Biol., 215, 403-410, 1990.

Avery, S. M., Moore, A., and Hutchison, M. L.: Fate of Escherichia coli originating from livestock faeces deposited directly onto pasture, Lett. Appl. Microbiol., 38, 355-359, 2004.

Balch, W. E., Fox, G. E., Magrum, L. J., Woese, C. R., and Wolfe, R. S.: Methanogens: re-evaluation of a unique biological group, Microbiol. Rev., 43, 260-296, 1979.
Brock, T. D.: Microbial life on Surtsey, Surtsey Research Progress Report, 2, 1966.

Brock, T. D.: Primary colonization of Surtsey, with special reference to the blue-green algae, Oikos, 24, 239-243, 1973.

Cockell, C. S., Olsson, K., Knowles, F., Kelly, L., Herrera, A., Thorsteinsson, T., and Marteinsson, V.: Bacteria in Weathered Basaltic Glass, Iceland, Geomicrobiol. J., 26, 491-507, 2009.

Degryse, E., Glansdorff, N., and Pierard, A.: Comparative analysis of extreme thermophilic bacteria belonging to genus Thermus, Arch. Microbiol., 117, 189-196, 1978.

Dunfield, K. E. and King, G. M.: Molecular analysis of carbon monoxide-oxidizing bacteria associated with recent Hawaiian volcanic deposits, App. Environ. Microb., 70, 4242-4248, 2004.

Edwards, K. J., Rogers, D. R., Wirsen, C. O., and McCollom, T. M.: Isolation and characterization of novel psychrophilic, neutrophilic, Fe-oxidizing, chemolithoautotrophic alpha- and, gamma-Proteobacteria from the deep sea, App. Environ. Microb., 69, 2906-2913, 2003.

Ernst, A.: The new flora of the volcanic island of Krakatau, University Press, Cambridge, 1908.

Fenchel, T., King, G. M., and Blackburn, T. H.: Bacterial biogeochemistry the ecophysiology of mineral cycling, Elsevier: Academic press, Amsterdam; Boston; Heidelberg [etc.], 2012.

Frederiksen, H. B., Pedersen, A. L., and Christensen, S.: Substrate induced respiration and microbial growth in soil during the primary succession on Surtsey, Iceland, Surtsey Res. Prog. Report, 11, 29-35, 2000.

Friðriksson, S.: Biological records on Surtsey, Surtsey Res. Prog. Report, 1, 19-22, 1965.

Girdwood, R. W. A., Fricker, C. R., Munro, D., Shedden, C. B., and Monaghan, P.: The incidence and significance of Salmonella carriage by gulls (Larus spp.) in Scotland, J. Hyg-Cambridge, 95, 229-241, 1985.

Gomez-Alvarez, V., King, G. M., and Nusslein, K.: Comparative bacterial diversity in recent Hawaiian volcanic deposits of different ages, Fems Microbiol. Ecol., 60, 60-73, 2007.

Huber, R., Burggraf, S., Mayer, T., Barns, S. M., Rossnagel, P., and Stetter, K. O.: Isolation of a hyperthermophilic archaeum predicted by in-situ RNA analysis, Nature, 376, 57-58, 1995.

Jakobsson, S. P. and Moore, J.: The Surtsey Research Drilling Project of 1979, Surtsey Res. Prog. Report, 9, 76-93, 1982.

Kallmeyer, J., Pockalny, R., Adhikari, R. R., Smith, D. C., and D'Hondt, S.: Global distribution of microbial abundance and biomass in subseafloor sediment, P. Natl. Acad. Sci. USA., 109, 16213-16216, 2012.

Kelly, L. C., Cockell, C. S., Piceno, Y. M., Andersen, G. L., Thorsteinsson, T., and Marteinsson, V.: Bacterial diversity of weathered terrestrial icelandic volcanic glasses, Microb. Ecol., 60, 740-752, 2010.

King, G. M. and Weber, C. F.: Interactions between bacterial carbon monoxide and hydrogen consumption and plant development on recent volcanic deposits, Isme J., 2, 195-203, 2008.

Kleber, M., Sollins, P., and Sutton, R.: A conceptual model of organo-mineral interactions in soils: self-assembly of organic molecular fragments into zonal structures on mineral surfaces, Biogeochemistry US, 85, 9-24, 2007.

Konhauser, K. O., Schiffman, P., and Fisher, Q. J.: Microbial mediation of authigenic clays during hydrothermal alteration of 
basaltic tephra, Kilauea Volcano, Geochem. Geophy., 3, 12-13, 2002.

Magnússon, B., Magnússon, S. H., Ólafsson, E., and Sigurdsson, B. D.: Plant colonization, succession and ecosystem development on Surtsey with reference to neighbouring islands, Biogeosciences, 11, 5521-5537, doi:10.5194/bg-11-5521-2014, 2014.

Marteinsson, V. T., Birrien, J. L., and Prieur, D.: In situ enrichment and isolation of thermophilic microorganisms from deep-sea vent environments, Can. J. Microbiol., 43, 694-697, 1997.

Marteinsson, V. T., Hauksdottir, S., Hobel, C. F. V., Kristmannsdottir, H., Hreggvidsson, G. O., and Kristjansson, J. K.: Phylogenetic diversity analysis of subterranean hot springs in Iceland, App. Environ. Microb., 67, 4242-4248, 2001a.

Marteinsson, V. T., Kristjansson, J. K., Kristmannsdottir, H., Dahlkvist, M., Saemundsson, K., Hannington, M., Petursdottir, S. K., Geptner, A., and Stoffers, P.: Discovery and description of giant submarine smectite cones on the seafloor in Eyjafjordur, northern Iceland, and a novel thermal microbial habitat, App. Environ. Microb., 67, 827-833, 2001 b.

Marteinsson, V. T., Runarsson, A., Stefansson, A., Thorsteinsson, T., Johannesson, T., Magnússon, S. H., Reynisson, E., Einarsson, B., Wade, N., Morrison, H. G., and Gaidos, E.: Microbial communities in the subglacial waters of the Vatnajokull ice cap, Iceland, Isme J., 7, 427-437, 2013.

Moore, J. G.: Tidal and leveling measurements on Surtsey JulyAugust, 1979, Surtsey Res. Prog. Report, 9, 98-101, 1982.

Odum, E. P.: Strategy of ecosystem development, Science, 164, 262-270, 1969.

Ólafsson, M. and Jakobsson, S. P.: Chemical composition of hydrothermal water and water-rock interactions on Surtsey volcanic island. A preliminary report., Surtsey Res. Prog. Report, 12, 29 38, 2009.

Pommepuy, M., Guillaud, J. F., Dupray, E., Derrien, A., Leguyader, F., and Cormier, M.: Enteric bacteria survival factors, Water Sci. Technol., 25, 93-103, 1992.

Ramette, A.: Multivariate analyses in microbial ecology, Fems Microbiology Ecology, 62, 142-160, 2007.

Roesch, L. F., Fulthorpe, R. R., Riva, A., Casella, G., Hadwin, A. K. M., Kent, A. D., Daroub, S. H., Camargo, F. A. O., Farmerie, W. G., and Triplett, E. W.: Pyrosequencing enumerates and contrasts soil microbial diversity, Isme Journal, 1, 283-290, 2007.

Schlesinger, W. H.: Biogeochemistry: an analysis of global change, Academic Press, San Diego, 1997.

Schwabe, G. H.: On the algal settlement in craters on Surtsey during summer 1968, Surtsey Res. Prog. Report, 5, 68-69, 1970.

Schwabe, G. H. and Behre, K.: Algae on Surtsey in 1969-1970, Surtsey Res Prog Report 6, 85-89, 1972.

Sigurdsson, B. D.: Ecosystem carbon fluxes of Leymus arenarius and Honckenya peploides on Surtsey in relation to water availability: a pilot study, Surtsey Res. Prog. Report, 12, 77-80, 2009.

Sigurdsson, B. D. and Magnússon, B.: Effects of seagulls on ecosystem respiration, soil nitrogen and vegetation cover on a pristine volcanic island, Surtsey, Iceland, Biogeosciences, 7, 883-891, doi:10.5194/bg-7-883-2010, 2010.

Sinsabaugh, R. L., Lauber, C. L., Weintraub, M. N., Ahmed, B., Allison, S. D., Crenshaw, C., Contosta, A. R., Cusack, D., Frey, S., Gallo, M. E., Gartner, T. B., Hobbie, S. E., Holland, K., Keeler, B. L., Powers, J. S., Stursova, M., Takacs-Vesbach, C., Waldrop, M. P., Wallenstein, M. D., Zak, D. R., and Zeglin, L. H.: Stoi- chiometry of soil enzyme activity at global scale, Ecol. Lett., 11, 1252-1264, 2008.

Skírnisdóttir, S., Hreggvidsson, G. O., Holst, O., and Kristjansson, J. K.: Isolation and characterization of a mixotrophic sulfuroxidizing Thermus scotoductus, Extremophiles: life under extreme conditions, 5, 45-51, 2001.

Sogin, M. L., Morrison, H. G., Huber, J. A., Mark Welch, D., Huse, S. M., Neal, P. R., Arrieta, J. M., and Herndl, G. J.: Microbial diversity in the deep sea and the underexplored "rare biosphere", P. Natl. Acad. Sci. USA, 103, 12115-12120, 2006.

Stetter, K. O., Lauerer, G, Thomm, M., and Neuner, A.: Isolation of extremely thermophilic sulfate reducers: evidence for a novel branch of Archaebacteria, Science, 236, 822-824, 1987.

Stetter, K. O., Huber, R., Blochl, E., Kurr, M., Eden, R. D., Fielder, M., Cash, H., and Vance, I.: Hyperthermophilic archaea are thriving in deep north-sea and Alaskan oil-reservoirs, Nature, 365, 743-745, 1993.

Sun, Y. H., Luo, Y. M., Wu, L. H., Li, Z. G., Song, J., and Christie, P.: Survival of faecal coliforms and hygiene risks in soils treated with municipal sewage sludges, Environ. Geochem. Hlth., 28, 97-101, 2006.

Tamura, K., Peterson, D., Peterson, N., Stecher, G., Nei, M., and Kumar, S.: MEGA5: Molecular Evolutionary Genetics Analysis Using Maximum Likelihood, Evolutionary Distance, and Maximum Parsimony Methods, Mol. Biol. Evol., 28, 2731-2739, 2011.

Thompson, J. D., Higgins, D. G., and Gibson, T. J.: CLUSTAL-W: improving the sensitivity of progressive multiple sequence alignment through sequence weighting, position-specific gap penalties and weight matrix choice, Nucleic Acids Res., 22, 46734680, 1994.

Vitousek, P. M. and Farrington, H.: Nutrient limitation and soil development: Experimental test of a biogeochemical theory, Biogeochemistry, 37, 63-75, 1997.

Walker, L. R. and del Moral, R.: Primary succession and ecosystem rehabilitation, Cambridge University Press, Cambridge, UK, 2003.

Whitman, W. B., Coleman, D. C., and Wiebe, W. J.: Prokaryotes: The unseen majority, P. Natl. Acad. Sci. USA., 95, 6578-6583, 1998.

Wright, E. S., Yilmaz, L. S., and Noguera, D. R.: DECIPHER, a Search-Based Approach to Chimera Identification for 16S rRNA Sequences, App. Environ. Microb., 78, 717-725, 2011.

Wu, L. L., Jacobson, A. D., Chen, H. C., and Hausner, M.: Characterization of elemental release during microbe-basalt interactions at $\mathrm{T}=28$ degrees C, Geochim. Cosmochimic. Ac., 71, 22242239, 2007.

Pórarinsson, S.: The Surtsey eruption: Course of events and the development of the new island, Surtsey Res. Prog. Report, 1, 51$55,1965$.

Pórarinsson, S.: The Surtsey eruption. Course of events during the year 1966, Surtsey Res. Prog. Report, 3, p. 84, 1967.

Pórarinsson, S.: The Surtsey eruption. Course of events during the year 1967, Surtsey Res. Prog. Report, 4, 143-148, 1968. 